\title{
Evaluation of the potential genotoxic activity in seawater of Asin Bay, Gulf of Gulluk, Mugla, Aegean coast of Turkey
}

\author{
Kocak E.*, Sakar S., Yetilmezsoy K., Bozyigit M. and Dalgic G. \\ Department of Environmental Engineering, Faculty of Civil Engineering, Yildiz Technical University, 34220, Davutpasa, Esenler, Istanbul, \\ Turkey
}

Received: 03/11/2016, Accepted: 01/12/2017, Available online: 06/12/2017

*to whom all correspondence should be addressed: e-mail: ekocak@yildiz.edu.tr

\begin{abstract}
This research examined the genotoxic activity in the seawater of Asin Bay (Gulf of Gulluk) located in Mugla, Turkey, Aegean coast of Turkey. Genotoxic activities of 66 raw samples, taken from 17 different stations in the spring and summer seasons of the year 2013, were determined by using in vitro mutagenicity assay SOS chromotest with Escherichia coli PQ37 strain bacteria activities. In the applied procedure, 6 -galactosidase (B-gal) activity, alkaline phosphatase (AP) activity, and different solvent controls were taken into account to generate reliable results in terms of the corrected induction factors (CIF) used as a quantitative measure of genotoxic activity level. The SOS chromotest procedure was simply and rapidly performed as an early assay to explore for whether a potential genotoxic activity was presence in the in the seawater of Asin Bay (Gulf of Gulluk) with no special measuring devices except a microplate reader. The implemented assay was successfully completed within only $24 \mathrm{~h}$ including the revival of the bacteria. The results showed that 11 samples (\%17 of total) were close to the threshold value of 1.5. The findings of this study clearly revealed that the seawater of Asin Bay (Gulf of Gulluk) had no potential genotoxic risks in terms of the organisms in marine ecosystem, since all of the calculated CIF values were determined to be below the threshold level. It was concluded that according to the SOS chromotest results, the levels of potential genotoxic agents were found to be under the limits for the offshore fishery.
\end{abstract}

Keywords: Asin Bay; genotoxicity; Gulf of Gulluk; offshore fishery; SOS chromotest

\section{Introduction}

The organisms that live in gulfs and bays are under the influence of various environmental factors. There are many known and unidentified sources of the total pollution in these marine systems (Albalat et al., 2002; Vlahogianni et al., 2007; Zorita et al., 2007; Naser, 2013). For instance, the presence of a heavy maritime traffic and the observation of uncontrolled applications in terms of bilge, ballast and the other wastewater can cause increase in the pollution over time (Dogan and Burak, 2007).
Considering the complex nature and dynamic characteristics of marine systems, environmental studies on the gulfs have still remained very superficial in terms of genotoxicological risks, and ecological effects of substances and associated hazards on both the environment and human health. It is therefore necessary to further examine assay systems to evaluate the substantial impacts of some persistent products before characterization of the entire pollution problem. Although the integration of physical and chemical methods usually provides a useful complementary approach for the water quality monitoring, however, presence of possible mutagenic compounds, recalcitrant substances, and soluble DNA-damaging agents may cause harmful effects on the aquatic environment (Lee and Steinert, 2003; Ohe et al., 2004; Kocak et al., 2010). In such cases, the physicochemical procedure alone cannot provide sufficient information on the potential toxicity of various unknown and often undetermined substances in a complex mixture. Some of these substances are genotoxic and are suspected to be a possible cause of the cancers observed in the last decades (Jolibois and Guerbet, 2005). Therefore, suitable genotoxicological tests should be incorporated into the existing water quality monitoring program to assess the potential risks to organisms in the environment (Isidori et al., 2005).

In recent years, water genotoxicity studies (Bombardier et al., 2001; Bartos et al., 2005; Cachot et al., 2006; Mansour et al., 2007; Gupta et al., 2009; Kocak et al., 2010) have become an interesting issue because the monitoring of water contamination for potentially carcinogenic and mutagenic compounds represents a major concern for human health. However, the evaluation of combined genotoxicity effects is a particularly difficult and complicated task because the genotoxic compounds likely to be found in the aquatic environment have a large chemical diversity and can come from various sources (Jolibois and Guerbet, 2005). Gebel and Koenig (1999) have reported that studies on combined genotoxicity may be carried out more easily using in vitro test systems, and therefore the combined effect of mixtures and environmental samples can be assessed rapidly and inexpensively without detailed knowledge of their chemical constituents. The SOS chromotest is one of the 
established in vitro test systems for the assessment of genotoxicity and used as a bacterial test that produces results within hours. The SOS chromotest allows the detection of primary DNA damaging agents on Escherichia coli PQ37 (Jolibois et al., 2003). It was developed by Quillardet et al. (1982) and was miniaturized by Fish et al., (1987) to run in 96-well microplates. It has been recommended for routine use in environmental applications requiring the assessment of genotoxic activity (Gonullu et al., 2001). Several studies (Gebel and Koenig, 1999; Legault et al., 1996; Ruiz and Marzin, 1997; Zani et al., 2005; Kocak et al., 2010) have also reported its usefulness in monitoring the genotoxicity of complex environmental matrices.

So far, most of the experimental studies have mainly focused on various advanced techniques for water quality improvement, but they have lacked through the integration of genotoxicity tests into the conventional procedures. To the best of the authors' knowledge, there are no systematic papers in the literature specifically devoted to the investigation and evaluation of the potential genotoxic activity in seawater of Asin Bay (Gulf of Gulluk) by using the SOS chromotest microplate assay. The existing studies related with the seawater in the offshore fish cultivating areas in Asin Bay (Gulf of Gulluk) are mainly intended for defining the bacteriological, physical and oceanographic situation; not for the genotoxic situation. Therefore, clarification of the place of the present topic in the scheme of water pollution control can be considered as a particular field of investigation to develop a sustainable water quality control strategy for the gulf systems located in offshore fish cultivating plants areas. For this reason, the present study aims at fulfilling the gap in this field by performing in vitro mutagenicity assay SOS chromotestbased investigations on a specific ecological system, such as Asin Bay (Gulf of Gulluk), Mugla, Aegean coast of Turkey.

Based on the above-mentioned facts, the specific objective of the present study was to investigate the genotoxic activities in seawater of Asin Bay (Gulf of Gulluk) by using the SOS chromotest microplate assay according to respective seasons and selected sampling locations.

\section{Materials and methods}

\subsection{Description of the study region}

Gulf of Gulluk (latitude $37^{\circ} 11^{\prime} 2^{\prime \prime}$ north and longitude $27^{\circ} 29^{\prime} 49^{\prime \prime}$ east), which is located in the boundaries of Mugla City, Milas District; Saricay River and Akyol Stream feeding the gulf were selected as the study area. It is surrounded by i) Kiyikislacik Neighbourhood and Asin Bay in the north, ii) Saricay Lagoon and Port of Gulluk in the east, iii) Gulluk Town in the southeast, iv) Bogazici Neighbourhood in the southwest, and v) Zeytinlikuyu Neighbourhood, Karaburun Lighthouse, and Aegean Sea in the west.

The gulf is under the influence of agricultural and microbial originated pollution arising from the residential areas. The basin of Saricay River and Akyol Stream compose the most important agricultural areas in the region. Mixing the residues of pesticides in significant amounts as a result of insensible usage to the gulf by the way of Saricay River and Akyol Stream is high probable. Additionally, olive mill wastewater of olive factories located intensely around the Saricay River compose an important source of pollution.

Gulf of Gulluk is located in a region concerning ecological culture fishery besides being one of the best tourism areas. So it has become the most important second biggest port after Izmir in the Aegean Sea.

\subsection{Sampling}

In the present study, 17 sampling locations, namely Meselik Island offshore (No 1), Middle of the offshore fish farms coded M49 and M50 (No 2), Tuzla Bay output Bogazici locality (No 3), Gulluk Village inner harbor (No 4), Akyol Stream inner Dalyan (No 5), Akyol Stream (No 6), Saricay River Savran Village entrance under bridge (No 7), Saricay River Dalyan entrance (No 8), Asin Bay (Gulf of Gulluk) Aegean Sea output (No 9), Middle of the offshore fish farms coded M46, M47, and M48 (No 10), Middle of the entrance of Ziraat Island (No 11), Between Tas Island and Ziraat Island (No 12), In front of the rocks of Tas Island (No 13), Kiyikislacik Village offshore (No 14), Mouth of Asin Bay (No 15), Mouth of Saricay and Akyol Rivers Dalyan (No 16), and Gulluk harbor (No 17), were selected to design a sampling network covering a wide range of determinants on Asin Bay (Figure $1 \mathrm{a}-\mathrm{d}$ ). Coordinates of the sampling locations were determined by using a GPS device (Garmin GPSMAP ${ }^{\circledR} 76 C S$ ) with a coded coordinate program (WGS 84). Water samples were collected on site at all sampling locations to explore the potential genotoxic variations during the study period (May 2013 - Agust 2013). Because genotoxic effects decrease during rainy weather, all of the samples were collected during dry weather conditions. This allowed us to eliminate the effect of the rain water on the genotoxic activity analyses (Jolibois et al., 2003; Kocak et al., 2010).

The collected samples were placed in $0.50 \mathrm{~L}$ polythylene bottles and put into ice-bag containers, and then transported back to the laboratory the same day. Prior to conducting genotoxic experiments, the samples were first filtered through $0.45 \mu \mathrm{m}$ pore diameter cellulose acetate filters. Thereafter, filtered samples were stored in sterile polythylene bottles at $4^{\circ} \mathrm{C}$ for no longer than seven days before genotoxicity assays (Kocak et al., 2010). During the study period, two seasonal samplings for year 2013 were performed in specific months (May, August), and a total of 66 samples were collected.

\subsection{SOS chromotest procedure}

The SOS chromotest is a colorimetric assay of enzymatic activities after incubating the test strain in the presence of various amounts of sample (Quillardet et al., 1982). The Escherichia coli PQ37 tester strain was kindly provided by M. Hofnung (Institut Pasteur, Paris, France). Jolibois and Guerbet (2006) reported that the SOS chromotest was performed without metabolic activation as described by Quillardet and Hofnung (1985) with modifications provided by Mersch-Sunderman et al. (1991) and Kevekordes et al. (1999). The test allows the detection of primary DNA (Deoxyribonucleic Acid)-damaging agents on a genetically 
engineered bacterium Escherichia coli PQ37 (Jolibois and Guerbet, 2006). In this assay, the 8 -galactosidase (B-gal) gene ( $/ a c Z)$ of the tester Escherichia coli PQ37 strain is fused to the bacterial sfiA SOS operon (Eck-Varanka et al., 2014). Thus, lacZ is concomitantly expressed in the case of bacterial SOS response; photometrically determined $B$-gal induction is indicative for the extent of SOS induction and bacterial genotoxicity. Bacterial alkaline phosphatase (AP) activity serves to determine the range of bacterial cytotoxicity; the ratio of 6 -gal/AP activity is termed induction factor (IF), and indicates the extent of SOS induction of a compound tested (Gebel and Koenig, 1999). The test is available as test kit with all the necessary materials included. No special measuring devices except a plate reader are needed. The test can be used as a qualitative test based on the use of a colour scale. It can be completed within $24 \mathrm{~h}$ including the revival of the bacteria. The test detects any primary DNA damage caused by genotoxins, and can be used for various kinds of aqueous samples (Dulger et al., 2008).
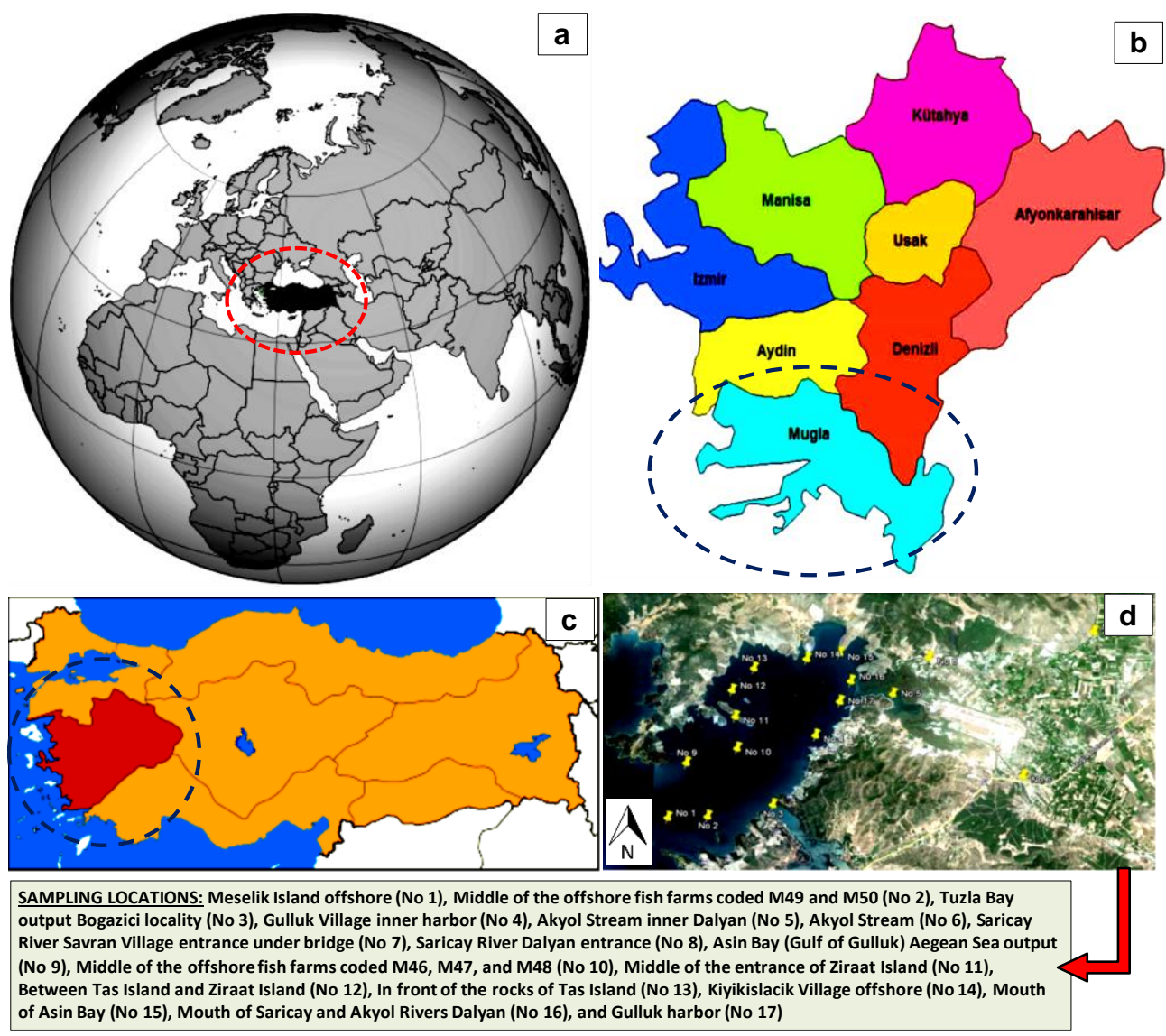

Figure 1. (a) Location of Turkey on the globe, (b) Boundaries of Mugla City in the southwest of Aegean Region of Turkey, (c) The Aegean region of Turkey, and (d) Satellite image of the study area showing the location of 17 sampling stations (yellow points) in Asin Bay (Gulf of Gulluk) located in Mugla, Aegean coast of Turkey

In this study, Escherichia coli PQ37 tester strain was kindly provided by Environmental Bio-Detection Products Inc. (Brampton, Ontario, Canada). Crude samples (100\% v/v.) for 17 sampling points were tested in triplicate starting from $100 \mathrm{~mL}$ sample equivalent for each cuvette. The test was performed at $37^{\circ} \mathrm{C}$ and the cuvettes were read after 2 $\mathrm{h}$ with a spectrophotometer. Sterile ultrapure water adjusted to $10 \%$ DMSO (dimethyl sulfoxide) used as a negative control, and 4NQO (4-Nitro-quinoline-oxide) was used as a positive control for the direct assay.

\subsection{Determination of genotoxic activity}

The SOS chromotest is based on the incubation of the bacteria with the sample, and subsequent determination of B-galactosidase (B-gal) activity (i.e., the level of SOS induction). Alkaline phosphatase (AP) activity is also measured as a toxicity control (Bombardier et al., 2001).
Alkaline phosphatase reduction factor (RF), 6 -gal induction factor (IF), and corrected induction factor (CIF) were calculated as described by the following equations (Legault et al., 1996; Kocak et al., 2010):

$$
\begin{aligned}
& R F=\frac{\left(O D_{405}\right)_{\text {mean }, t}}{\left(O D_{405}\right)_{\text {mean }, c}} \\
& I F=\frac{\left(O D_{620}\right)_{\text {mean }, t}}{\left(O D_{620}\right)_{\text {mean }, c}} \\
& C I F=\frac{R F}{I F}
\end{aligned}
$$


where $\left(O D_{405}\right)_{\text {mean }}$ and $\left(O D_{620}\right)_{\text {mean }}$ are the means of optical density (OD) readings taken at 620 (B-gal) and $405 \mathrm{~nm}(\mathrm{AP})$, and $t$ and $c$ refer to test and control dilutions, respectively. Bombardier et al. (2001) have reported that the RF and IF values account for the background activity of the control.
The criterion to consider a sample as positive in the SOS chromotest differs between authors (Kocak et al., 2010; Legault et al., 1996; Guzzella et al., 2006; Cachot et al., 2006; Gebel and Koenig, 1999; Ortolan and Ayub, 2007) (Table 1).

Table 1. Genotoxic activity levels and the corresponding threshold values defined in different studies

\begin{tabular}{|c|c|c|}
\hline Genotoxic activity levels & $\begin{array}{l}\text { Corrected } \\
\text { induction factors } \\
\text { (CIF) }\end{array}$ & Reference and region \\
\hline Genotoxic & $>1.5$ & \multirow{2}{*}{$\begin{array}{l}\text { Kocak et al., (2010), Turkey; Guzzella et al., (2006), Italy } \\
\text { Legault et al., (1996), Canada }\end{array}$} \\
\hline SOS response & $>1.2$ & \\
\hline High genotoxic & $>2.0$ & \multirow{3}{*}{$\begin{array}{l}\text { Cachot et al., (2006), France; Gebel and Koenig, (1999), } \\
\text { Germany }\end{array}$} \\
\hline Moderate genotoxic & $1.5-2.0$ & \\
\hline Not genotoxic & $<1.5$ & \\
\hline Genotoxic & $\geq 2.0$ & \multirow{2}{*}{ Ortolan and Ayub (2007), Brazil } \\
\hline Not genotoxic & $=1.0$ & \\
\hline
\end{tabular}

\subsection{Analytical procedure}

All SOS chromotest analyses were conducted based on the EBPI (Environmental Bio-Detection Products Inc.) protocols (EBPI, 2008). All experiments were applied under steril conditions using a biosafety cabinet (Berner, Germany). Experimental equipments (i.e., micropipettes, Eppendorf pipettes) were sterilized at $121^{\circ} \mathrm{C}$ and 10.6 bar for $15 \mathrm{~min}$ by using an autoclave (Nuve OT 40L, Turkey). A temperature-controlled incubator (Thermo, Electron Corporation, Waltham, MA, USA) was used to allow growth of the bacteria and development of enzymatic activities at a stable temperature of $37^{\circ} \mathrm{C}$. Optical density values of the grown cultures at $600 \mathrm{~nm}$ were measured by a UV-VISSpectrophotometer (UV-1202, UV-VIS, Shimadzu Corp., Japan) with a special quartz cuvet of $1 \mathrm{~cm}$ light path length. ATP and 6 -gal activities were measured by using a Microplate Reader (ChemWell ${ }^{\circledR}$ Awarenges Tech. 2900, USA).

\subsection{Statistical analysis}

In this study, the CIF values obtained for each sampling point in 2013 Spring and 2013 Summer were used as a quantitative measurement of genotoxic activities in the studied region, and the corresponding data sets were statistically compared by means of a parametric test (matched pair t-test or paired t-test or paired samples ttest or dependent t-test) within the framework of StatsDirect (V2.7.2, StatsDirect, Ltd., Altrincham, Cheshire, UK) statistical software package operated on a PC platform (Casper Excalibur, Intel ${ }^{\circledR}$ Core $^{\mathrm{TM}}$ i7-7700HQ CPU, $2.81 \mathrm{GHz}$, 16 GB of RAM, 64-bit). This type of test was used as beforeand-after comparison, since the CIF data sets were obtained from the sampling points at different times (i.e., 2013 Spring and 2013 Summer).

Prior to applying the parametric test, the Shapiro-Wilk W and the Levene's tests were consecutively implemented as preconditions, in order to appraise whether the obtained CIF subsets of 2013 Spring and 2013 Summer had either a normal or a non-normal distribution, and to evaluate whether the variances (or standard deviations) of the paired groups were either homogeneous or unequal.

The statistical results were assessed with various descriptive statistics, such as two-sided $p$ values, $t$ statistics, mean of differences, standard deviation, standard error, and power values (or probability of detecting a true effect), to reflect the statistical significance between the paired groups for an alpha $(\alpha)$ level of 0.05 (or $95 \%$ confidence).

\section{Results and discussions}

\subsection{SOS chromotest responses}

The SOS chromotest procedure was performed to determine the potential genotoxic activities of Asin Bay (Gulf of Gulluk) seawater samples. Based on the obtained CIF values, the results clearly pointed out that no potential genotoxicity was found in the studied region. Results of SOS Chromotest for the samples taken from 17 stations (No 1- No 17) at different depths in the spring and summer seasons of the year 2013 are given Table 2 .

As seen from Table 2, results of the present SOS chromotest for the 17 sampling stations indicated that the CIF values were determined within the ranges of 0.82-1.15 and 0.59-1.08, respectively, for 2013 Spring and 2013 Summer. The highest CIF values in 2013 Spring and 2013 Summer were found at the sampling points of Saricay River Savran Village entrance under bridge (No 7), and Mouth of Asin Bay (No 15), respectively. The mean CIF values were obtained as $0.96 \pm 0.093$ and $0.85 \pm 0.121$, respectively, for 2013 Spring and 2013 Summer.

The results of the Shapiro-Wilk $W$ tests showed no evidence of non-normality for the paired groups of 2013 Spring ( $W=0.9522, p=0.1426>0.05, n=34)$ and 2013 Summer $(W=0.9828, p=0.8553>0.05, n=34)$. For this case, the supposition of normality was corroborated for both groups in favor of the null hypothesis $\left(\mathrm{H}_{0}\right.$ : the sample is taken from a normal distribution, $p>\alpha=0.05$ ) of the Shapiro-Wilk W test, since both samples were taken from a normal distribution for an alpha $(\alpha)$ level of 0.05 (or $95 \%$ confidence). 
Table 2. Results of SOS Chromotest for the samples taken from 17 stations (No 1- No 17) at different depths in the spring and summer

\begin{tabular}{|c|c|c|c|c|}
\hline \multirow{2}{*}{ Sampling point } & \multirow{2}{*}{ Place } & \multirow{2}{*}{ Sampling depth } & 2013 - Spring & 2013 - Summer \\
\hline & & & $\mathrm{CIF}=\mathrm{RF} / \mathrm{IF}$ & $\mathrm{CIF}=\mathrm{RF} / \mathrm{IF}$ \\
\hline \multirow{3}{*}{ No 1} & \multirow{3}{*}{ Meselik Island off-shore } & Surface & 0.93 & 0.75 \\
\hline & & Medium $17 \mathrm{~m}$ & 0.84 & 0.98 \\
\hline & & Bottom 35 m & 1.14 & 0.82 \\
\hline \multirow{3}{*}{ No 2} & \multirow{3}{*}{$\begin{array}{l}\text { Middle of the M49 and } \\
\text { M50 coded fish farms }\end{array}$} & Surface & 1.00 & 0.95 \\
\hline & & Medium $16 \mathrm{~m}$ & 0.91 & 0.91 \\
\hline & & Bottom $32 \mathrm{~m}$ & 1.00 & 0.81 \\
\hline \multirow{2}{*}{ No 3} & \multirow{2}{*}{$\begin{array}{c}\text { Tuzla Bay out Bogazici } \\
\text { locality }\end{array}$} & Surface & 0.84 & 0.74 \\
\hline & & Bottom $15 \mathrm{~m}$ & 0.98 & 0.81 \\
\hline \multirow{2}{*}{ No 4} & \multirow{2}{*}{$\begin{array}{c}\text { Gulluk Village inner } \\
\text { harbor } \\
\end{array}$} & Surface & 1.10 & 0.94 \\
\hline & & Bottom $15 \mathrm{~m}$ & 1.08 & 0.81 \\
\hline No 5 & $\begin{array}{c}\text { Akyol Stream inner } \\
\text { Dalyan }\end{array}$ & Surface & 0.87 & 0.87 \\
\hline No 6 & Akyol Stream & Surface & 1.03 & 0.92 \\
\hline & Saricay River Savran & & & \\
\hline No 7 & $\begin{array}{c}\text { Village entrance under } \\
\text { bridge }\end{array}$ & Surface & 1.15 & 0.71 \\
\hline No 8 & $\begin{array}{c}\text { Saricay River Dalyan } \\
\text { entrance }\end{array}$ & Surface & 0.91 & 0.75 \\
\hline \multirow{3}{*}{ No 9} & \multirow{3}{*}{$\begin{array}{l}\text { Asin Bay (Gulf of Gulluk) } \\
\text { Aegean Sea output }\end{array}$} & Surface & 0.98 & 0.88 \\
\hline & & Medium15 m & 0.82 & 0.79 \\
\hline & & Bottom $30 \mathrm{~m}$ & 0.94 & 0.83 \\
\hline \multirow{3}{*}{ No 10} & \multirow{3}{*}{$\begin{array}{l}\text { Middle of the offshore } \\
\text { fish farms coded M46, } \\
\text { M47 and M48 }\end{array}$} & Surface & 0.84 & 0.67 \\
\hline & & Medium $15 \mathrm{~m}$ & 0.97 & 0.89 \\
\hline & & Bottom $30 \mathrm{~m}$ & 0.97 & 0.79 \\
\hline \multirow{2}{*}{ No 11} & \multirow{2}{*}{$\begin{array}{c}\text { Middle of the entrance of } \\
\text { Ziraat Island }\end{array}$} & Surface & 1.03 & 0.79 \\
\hline & & Bottom $20 \mathrm{~m}$ & 0.87 & 0.83 \\
\hline \multirow{2}{*}{ No 12} & \multirow{2}{*}{$\begin{array}{l}\text { Between Tas Island and } \\
\text { Ziraat Island }\end{array}$} & Surface & 0.87 & 1.08 \\
\hline & & Bottom $12 \mathrm{~m}$ & 0.98 & 0.86 \\
\hline \multirow{2}{*}{ No 13} & \multirow{2}{*}{$\begin{array}{c}\text { In front of the rocks of Tas } \\
\text { Island }\end{array}$} & Surface & 1.09 & 0.66 \\
\hline & & Bottom $12 \mathrm{~m}$ & 0.98 & 0.99 \\
\hline \multirow{2}{*}{ No 14} & \multirow{2}{*}{$\begin{array}{c}\text { Kiyikislacik Village } \\
\text { offshore }\end{array}$} & Surface & 0.94 & 0.92 \\
\hline & & Bottom $10 \mathrm{~m}$ & 1.02 & 0.83 \\
\hline \multirow{2}{*}{ No 15} & \multirow{2}{*}{ Mouth of Asin Bay } & Surface & 0.86 & 1.08 \\
\hline & & Bottom $10 \mathrm{~m}$ & 0.84 & 0.59 \\
\hline \multirow{2}{*}{ No 16} & \multirow{2}{*}{$\begin{array}{l}\text { Mouth of Saricay and } \\
\text { Akyol Rivers Dalyan }\end{array}$} & Surface & 0.90 & 0.76 \\
\hline & & Bottom 10 m & 0.94 & 0.67 \\
\hline \multirow{2}{*}{ No 17} & Gulluk Harher & Surface & 0.94 & 1.00 \\
\hline & Guiluk Hardor & Bottom $15 \mathrm{~m}$ & 1.11 & 1.05 \\
\hline
\end{tabular}

CIF: Corrected Induction Factor; RF: Reduction Factor; IF: Induction Factor

The result of the Levene's (W50) test as an option with one way analysis of variance (ANOVA) confirmed the equality/homogeneity of variances for the paired groups of 2013 Spring and 2013 Summer $(F=1.6141, d f=(1,66)$, $p=0.2084>0.05)$. Hereby, the null hypothesis $\left(\mathrm{H}_{0}\right.$ : the samples are from identical distributions, $p>\alpha=0.05$ ) of the Levene's test was not rejected in favor of the alternative hypothesis $\left(\mathrm{H}_{\mathrm{a}}\right.$ : the samples are not from identical distributions, $p<\alpha=0.05$ ), since it could not be inferred a statistically significant difference between the variances of the paired groups of 2013 Spring and 2013 Summer.

As summarized above, the predetermined $p$ values obtained from the Shapiro-Wilk W and the Levene's tests confirmed the applicability of the parametric test. The result of the paired t-test confirmed with $95 \%$ certainty that a significant difference was found between the CIF values in the paired groups of 2013 Spring and 2013 Summer, so that the null hypothesis of no difference between the means was clearly rejected (mean of differences $=0.1159$, standard deviation $=0.1503$, standard error $=0.026, n=34,95 \% \mathrm{Cl}$ (confiendence interval) $=0.063$ to $0.1683, d f=33, t=4.4953$, two-sided $p<0.0001$, and power (for $5 \%$ significance) $=99.04 \%$ ). Although no potential genotoxic impacts $(\mathrm{CIF}<1.5)$ were found in the seawater of Asin Bay (Gulf of Gulluk) for the samples obtained in 2013 Spring and 2013 Summer periods, statistical analysis of the results revealed that the seasonal variations in terms of CIF values were noticeable in the reagion $(p<0.05)$. This may be ascribed to seasonal thermodynamic and hydrodynamic conditions, as well as to 
other meteorological factors dominated in this marine system.

Overall, in this study, all of the calculated CIF values were obtained to be below the 1.5 threshold level (Kocak et al., 2010, Legault et al., 1996, Guzzella et al., 2006, Cachot et al., 2006, Gebel and Koenig, 1999, Ortolan and Ayub, 2007). When the CIF for any of the test concentrations reached 1.5, the test substance was scored as a significant genotoxic. However, the SOS chromotest results clearly concluded that no potential genotoxic impacts were found in the seawater of Asin Bay (Gulf of Gulluk).

\subsection{Comparisons with literature data}

Recently, various types of water and wastewater samples have been introduced for the genotoxicological assessment by using the SOS chromotest (on Escherichia coli PQ37). For instance, Jolibois and Guerbet (2005) have evaluated the genotoxic potential of different wastewaters including industrial, hospital and domestic wastewater. In the study, out of a total of 71 daytime samples tested, 46 (65\%) have found to be positive in at least one assay: 22 samples out of 33 in January (67\%), and 24 samples out of 38 in April (63\%), and genotixic activity values have ranged from 0.88 to 2.15. On the basis of the obtained results, the authors have recommended that the different types of wastewaters present a genotoxic risk, and complimentary studies should be undertaken in the analytical field in order to try to identify and quantify the compounds responsible for the genotoxicity.

Guzzella et al., (2006) conducted experimental studies to investigate the potential genotoxic effects of surface drinking water treated with chlorine and alternative disinfectants, such as sodium hypochlorite ( $\mathrm{NaClO}$ ), chlorine dioxide $\left(\mathrm{ClO}_{2}\right)$ and peracetic acid (PAA). Among the

Table 3. Comparison of different process typologies on genotoxic assessment of various types of water and wastewater samples

\begin{tabular}{|c|c|c|c|}
\hline Sample type & Potential genotoxic hazards & CIF levels & $\begin{array}{l}\text { Reference and } \\
\text { region }\end{array}$ \\
\hline $\begin{array}{c}\text { Seawater of Asin Bay (Gulf of Gulluk) } \\
\text { located in Mugla, Aegean coast of } \\
\text { Turkey }\end{array}$ & $\begin{array}{l}\text { Offshore fishery-related potential genotoxic } \\
\text { agents }\end{array}$ & $\begin{array}{l}0.82-1.15 \text { (for } \\
2013 \text { Spring) } \\
0.59-1.08 \text { (for } \\
2013 \text { Summer) }\end{array}$ & $\begin{array}{l}\text { Present study, } \\
\text { Turkey }\end{array}$ \\
\hline $\begin{array}{l}\text { Industrial, hospital and domestic } \\
\text { wastewater }\end{array}$ & $\begin{array}{l}\text { Anticancer drugs (mitomycin, adriamycin, } \\
\text { bleomycin, daunomycin, etc.) }\end{array}$ & $0.88-2.15$ & $\begin{array}{c}\text { Jolibois and } \\
\text { Guerbet (2005), } \\
\text { France }\end{array}$ \\
\hline $\begin{array}{l}\text { Surface drinking water treated with } \\
\text { chlorine and alternative disinfectants }\end{array}$ & $\mathrm{NaClO}, \mathrm{ClO}_{2}, \mathrm{PAAs}$ & $\begin{array}{l}\text { Moderate and high } \\
\text { levels defined in } \\
\text { the study }\end{array}$ & $\begin{array}{l}\text { Guzzella et al. } \\
\text { (2006), Italy }\end{array}$ \\
\hline Sediment samples & PAHs, PCBs and metals & $0.80-8.96$ & $\begin{array}{l}\text { Cachot et al. } \\
\text { (2006), France }\end{array}$ \\
\hline $\begin{array}{l}\text { Domestic and industrial effluent } \\
\text { samples (organic and inorganic chemical } \\
\text { plants, metallurgical plants, pulp and } \\
\text { paper mills, and municipal wastewater } \\
\text { treatment plants) }\end{array}$ & Soluble DNA-damaging agents & $1.56-1.88$ & $\begin{array}{l}\text { Legault et al. } \\
\text { (1996), Canada }\end{array}$ \\
\hline
\end{tabular}

The performance data reveals that a wide range of CIF values has been observed depending on the characteristics and complex nature of the studied water and wastewater tested disinfectants, $\mathrm{NaClO}$ and $\mathrm{ClO}_{2}$ have increased water genotoxicity, whereas PAA has slightly reduced raw water activity. The authors have concluded that as a consequence of the different chemical species present in the raw lake water, the disinfection processes can increase or decrease the raw water effect.

Cachot et al. (2006), have performed chemical and toxicological analyses on 17 sediments to characterize the genotoxicity in a specific estuary (Seine, France). In the study, many potent mutagenic and/or carcinogenic compounds including polycyclic aromatic hydrocarbons $(\mathrm{PAH})$, polychlorinated biphenyls (PCB) and metals have been detected. Based on both embryotoxicity and in vitro genotoxicity (SOS chromotest) assays, the authors have concluded that sediments from the upper Seine Estuary may constitute a major source of pollution and hazards for species living or feeding in the area.

Another genotoxicologial study has been undertaken by Legault et al. (1996), for detecting the soluble genotoxic activities in domestic and industrial effluent samples (organic and inorganic chemical plants, metallurgical plants, pulp and paper mills, and municipal wastewater treatment plants). The authors have observed that 37 (77\%) of 48 effluent samples elicited a significant induction of the Escherichia coli PQ37 SOS response, and CIF values have been determined between 1.56 and 1.88. The study concluded that SOS chromotest was sufficiently sensitive to screen for the presence of soluble DNA-damaging agents in a wide variety of unconcentrated wastewater samples.

Table 3 summarizes results of some experimental data concerning the comparison of various process typologies on genotoxic assessment of various types of water and wastewater samples. matrices. High genotoxic activity values are probably due to the presence of several mutagenic and carcinogenic agents, persistent components, soluble DNA-damaging 
products, recalcitrant substances, and other undesirable impurities in the collected samples. It is apparent from the previous studies that although various chemical compounds have been widely used in numerous industrial and environmental applications, however, relatively few genotoxicological investigations are available in the literature.

The CIF values, which were equal or greater than 1.5, were considered to represent a significant genotoxic activity, as suggested by most of the authors (Kocak et al., 2010; Jolibois and Guerbet, 2005; Margulis et al., 2003; MerschSundermann et al., 1991; Mersch-Sundermann et al., 1992). The findings of the present study obviously revealed that the seawater of Asin Bay (Gulf of Gulluk) showed no potential genotoxic risks on the organisms living in the studied marine ecosystem, since all of the obtained CIF values were found to be below the threshold level of 1.5.

\section{Conclusions}

In the study, the genotoxic activity examined in the seawater of Asin Bay (Gulf of Gulluk) located in Mugla, Aegean coast of Turkey. Genotoxic activities by using SOS chromotest of 66 raw samples taken from 17 different stations in the spring and summer seasons of the year 2013, were determined as CIF values. The results showed that 11 samples (about \%17 of total) were close to the threshold value of 1.5. It was concluded that according to the SOS chromotest results, the levels of potential genotoxic agents were found to be under the limits for the offshore fishery.

The work described here is the first report from an integrated study investigating the genotoxicity of Asin Bay (Gulf of Gulluk). Although the SOS chromotest results showed that samples did not have have any genotoxic effects on the aquatic environment, additional studies will have to be applied to better research the pollution. Further investigations will also detect the level of genotoxicity for different stations in the study area. The results of this research clearly point out that the seawater of Asin Bay (Gulf of Gulluk) has no potentially hazardous impact to the aquatic environment.

\section{Acknowledgements}

The authors would like to thank Research Project Coordinator of Yildiz Technical University for supporting this study financially under the number 2013-05-02-KAP03.

\section{References}

Albalat A., Potrykus J., Pempkowiak J. and Porte C. (2002), Assessment of organotin pollution along the Polish coast (Baltic Sea) by using mussels and fish as sentinel organisms, Chemosphere, 47(2), 165-171.

Bartos T., Skarek M., Cupr P., Kosubova P. and Holoubek I. (2005), Genotoxic activity of a technical toxaphene mixture and its photodegradation products in SOS genotoxicity tests, Mutation Research, 565(2), 113-120.

Bombardier M., Bermingham N., Legault R. and Fouquet A. (2001), Evaluation of an SOS-chromotest-based approach for the isolation and detection of sediment-associated genotoxins, Chemosphere, 42, 931-944.
Cachot J., Geffard O., Augagneur S., Lacroix S., Le Menach K., Peluhet L., Couteau J., Denier X., Devier M.H., Pottier D. and Budzinski H. (2006), Evidence of genotoxicity related to high PAH content of sediments in the upper part of the Seine Estuary (Normandy, France), Aquatic Toxicology, 79(3), 257-267.

Dogan E. and Burak S. (2007), Ship-originated pollution in the Istanbul strait (Bosphorus) and Marmara Sea, Journal of Coastal Research, 23(2), 388-394.

Dulger M., Yilmaz S., Kocak E. and Petek M. (2008), Determination of genotoxic pollution of Ayamama and Haramidere streams with SOS-chromotest method, Fatih University, University Students' 3rd Environmental Problem Congress, CESKO 2008, 149-156, Istanbul.

Eck-Varanka B., Horváth E., Ferincz Á., Paulovits G. and Kováts N. (2014), Comparative Assessment of the Mussel Micronucleus Test Versus Bacterial Bioassays for Genotoxicity Testing of Benzo [a] pyrene, Hungarian Journal of Industry and Chemistry, 42(1), 1-5.

EBPI (Environmental Bio-Detection Products Inc.), The SOSchromotest Version 6.3, Instruction for Use, Canada, 2008.

Fish F., Lampert I., Halachmi A., Riesenfeld G. and Herzberg M. (1987), The SOS chromotest kit: A rapid method for the detection of genotoxicity, Environmental Toxicology, 2(2), 135-147.

Gebel T. and Koenig A. (1999), Impact of dimethyl sulfoxide and examples of combined genotoxicity in the SOS chromotest, Mutation Research/Genetic Toxicology and Environmental Mutagenesis, 444(2), 405-411.

Gonullu M.T., Bayhan H., Arslankaya E., Kurt U., Tosun I. and Apaydin O. (2001), Pollution capability of the Golden Horn bentic sediments in March 2001, Halic Symposium, Istanbul (in Turkish).

Gupta P., Mathur N., Bhatnagar P., Nagar P. and Srivastava S. (2009), Genotoxicity evaluation of hospital wastewaters, Ecotoxicology and Environmental Safety, 72(7), 1925-1932.

Guzzella L., Di Caterino F., Monarca S., Zani C., Feretti D., Zerbini I., Nardi G., Buschini A., Poli P. and Rossi C. (2006), Detection of mutagens in water-distribution systems after disinfection, Mutation Research/Genetic Toxicology and Environmental Mutagenesis, 608(1), 72-81.

Isidori M., Lavorgna M., Nardelli A., Pascarella L. and Parrella A. (2005), Toxic and genotoxic evaluation of six antibiotics on non-target organisms, Science of the Total Environment, 346(1), 87-98.

Jolibois B. and Guerbet M. (2005), Evaluation of industrial, hospital and domestic wastewater genotoxicity with the Salmonella fluctuation test and the SOS chromotest, Mutation Research/Genetic Toxicology and Environmental Mutagenesis, 565(2), 151-162.

Jolibois B. and Guerbet M. (2006), Hospital wastewater genotoxicity, Annals of Occupational Hygiene, 50(2), 189-196.

Jolibois B., Guerbet M. and Vassal S. (2003), Detection of hospital wastewater genotoxicity with the SOS chromotest and Ames fluctuation test, Chemosphere, 51(6), 539-543.

Kevekordes S., Mersch-Sundermann V., Burghaus C.M., Spielberger J., Schmeiser H.H., Arlt V.M. and Dunkelberg H. (1999), SOS induction of selected naturally occurring substances in Escherichia coli (SOS chromotest), Mutation Research/Genetic Toxicology and Environmental Mutagenesis, 445(1), 81-91. 
Kocak E., Yetilmezsoy K., Gonullu M.T. and Petek M. (2010), A statistical evaluation of the potential genotoxic activity in the surface waters of the Golden Horn Estuary, Marine Pollution Bulletin, 60(10), 1708-1717.

Lee R.F. and Steinert S. (2003), Use of the single cell gel electrophoresis/comet assay for detecting DNA damage in aquatic (marine and freshwater) animals, Mutation Research/Reviews in Mutation Research, 544(1), 43-64.

Legault R., Blake C. and Trottier S. (1996), Detecting genotoxic activity in industrial effluents using the SOS chromotest microplate assay, Environmental Toxicology, 11(2), 151-165.

Mansour H.B., Corroler D., Barillier D., Ghedira K., Chekir L. and Mosrati R. (2007), Evaluation of genotoxicity and pro-oxidant effect of the azo dyes: Acids yellow 17, violet 7 and orange 52, and of their degradation products by Pseudomonas putida mt-2, Food and Chemical Toxicology, 45(9), 1670-1677.

Margulis A.B., I'inskaya O.N., Kolpakov A.I. and El'-Registan G.I. (2003), Induction of SOS response by autoregulatory factors of microorganisms, Russian Journal of Genetics, 39(9), 993-996.

Mersch-Sundermann V., Kevekordes S. and Mochayedi S. (1991), Sources of variability of the Escherichia coli PQ37 genotoxicity assay (SOS chromotest), Mutation Research/Environmental Mutagenesis and Related Subjects, 252(1), 51-60.

Mersch-Sundermann V., Kern, S. and Wintermann F. (1992), Genotoxicity of nitrated polycyclic aromatic hydrocarbons and related structures on E.coli PQ37 (SOS chromotest), Environ. Mol. Mutagen., 18, 41-50.

Naser H.A. (2013), Assessment and management of heavy metal pollution in the marine environment of the Arabian Gulf: a review, Marine Pollution Bulletin, 72(1), 6-13.

Ohe T., Watanabe T. and Wakabayashi K. (2004), Mutagens in surface waters: a review, Mutation Research/Reviews in Mutation Research, 567(2), 109-149.

Ortolan M.D.G.S. and Ayub M.A.Z. (2007), Cytotoxicity and genotoxicity of untreated hospital effluents, Brazilian Archives of Biology and Technology, 50(4), 637-643.

Ruiz M.J. and Marzin D. (1997), Genotoxicity of six pesticides by Salmonella mutagenicity test and SOS chromotest, Mutation Research/Genetic Toxicology and Environmental Mutagenesis, 390(3), 245-255.

Quillardet P. and Hofnung M. (1985), The SOS chromotest, a colorimetric bacterial assay for genotoxins: procedures, Mutation Research/Environmental Mutagenesis and Related Subjects, 147(3), 65-78.

Quillardet P., Huisman O., D'Ari R. and Hofnung M. (1982), SOS chromotest, a direct assay of induction of an SOS function in Escherichia coli K12 to measure genotoxicity, Proceedings of the National Academy of Sciences, 79(19), 5971-5975.

Vlahogianni T., Dassenakis M., Scoullos M.J. and Valavanidis A. (2007), Integrated use of biomarkers (superoxide dismutase, catalase and lipid peroxidation) in mussels Mytilus galloprovincialis for assessing heavy metals' pollution in coastal areas from the Saronikos Gulf of Greece, Marine Pollution Bulletin, 54(9), 1361-1371.

Zani C., Feretti D., Buschini A., Poli P., Rossi C., Guzzella L., Ceternio D.F. and Monarca S. (2005), Toxicity and genotoxicity of surface water before and after various potabilization steps, Mutation Research/Genetic Toxicology and Environmental Mutagenesis, 587(1), 26-37.
Zorita I., Apraiz I., Ortiz-Zarragoitia M., Orbea A., Cancio I., Soto M., Marigómez I. and Cajaraville M.P. (2007), Assessment of biological effects of environmental pollution along the NW Mediterranean Sea using mussels as sentinel organisms, Environmental Pollution, 148(1), 236-250. 